\title{
Toxicology Evaluation of Realgar-Containing Niu-Huang-Jie-Du Pian as Compared to Arsenicals in Cell Cultures and in Mice
}

\author{
Jia-Wei Miao, ${ }^{1,2}$ Shi-Xia Liang, ${ }^{1}$ Qin Wu, ${ }^{1}$ Jie Liu, ${ }^{1,3}$ and An-Sheng Sun ${ }^{1}$ \\ ${ }^{1}$ Key Lab of Basic Pharmacology, Zunyi Medical College, Zunyi 563000, China \\ ${ }^{2}$ Chongqing Three Gorges Medical College, Chongqing 404120, China \\ ${ }^{3}$ University of Kansas Medical Center, Kansas KS 66160, USA
}

Correspondence should be addressed to Jie Liu, jliu@kumc.edu and An-Sheng Sun, anshengsun@yahoo.com.cn

Received 5 June 2011; Accepted 7 July 2011

Academic Editors: K. M. Erikson and A. I. Haza

Copyright (C) 2011 Jia-Wei Miao et al. This is an open access article distributed under the Creative Commons Attribution License, which permits unrestricted use, distribution, and reproduction in any medium, provided the original work is properly cited.

\begin{abstract}
Niu-Huang-Jie-Du Pian (NHJD) is a widely used traditional Chinese medicine containing realgar $\left(\mathrm{As}_{4} \mathrm{~S}_{4}\right)$. Realgar has been included in many traditional medicines, but is often taken as arsenite for risk assessment. To evaluate true risk of realgar and realgar-containing $N H J D$, their toxicity was compared with common arsenicals. In cultured cells, the $\mathrm{LC}_{50}$ for $N H J D(1200 \mu \mathrm{M})$ and realgar $(2000 \mu \mathrm{M})$ was much higher than arsenite $(35 \mu \mathrm{M})$, arsenic trioxide $(280 \mu \mathrm{M})$, and arsenate $(400 \mu \mathrm{M})$. Acute toxicity in mice showed more severe liver and kidney injury after arsenite or arsenate, but was mild after realgar and $N H J D$, corresponding to cellular and tissue arsenic accumulation. The expressions of arsenic-sensitive stress gene metallothionein-1 were increased 37-folds after arsenite or arsenate, but were unaltered after NHJD and realgar. Thus, realgar and NHJD are much less toxic than arsenite and arsenate. The use of total arsenic to evaluate the safety of realgar and realgar-containing NHJD is inappropriate.
\end{abstract}

\section{Introduction}

Realgar $\left(90 \%\right.$ as $\left.\mathrm{As}_{4} \mathrm{~S}_{4}\right)$ has been used in traditional Chinese medicines [1, 2] and in Indian Ayurvedic medicines [3] for thousands of years and claimed to have therapeutic effects in these remedies. However, arsenic (As) is a highly toxic substance and its risk in traditional remedies is of concern [4-6]. Hundreds of traditional medicines are forbidden in the USA or European market because of the contents of As are higher than the allowable limits for food and drugs [2], and over $20 \%$ of online-sold Ayurvedic medicines were demanded for rigorous regulation for heavy metal contents [6]. The Chinese Pharmacopeia Committee has reduced the allowable As contents in traditional medicine recipes by as much as $65 \%$, but As contents are still thousands-fold over the health food standards. More studies are therefore recommended to evaluate the true risk of metal-containing traditional medicines [7].

Niu-Huang-Jie-Du Pian (NHJD, 牛黄解毒片) is a popular realgar-containing traditional Chinese medicine (http:// www.wickpedia.org/), which can be easily obtained in Chinese grocery stores worldwide. NHJD is composed of realgar (6.4\%), Niu-Huang (Calculus bovis), Huang-Qin (Radix scutellariae, rhubarb), Ju-Geng (Platycodon grandiflorum), Gan-Cao (Radix glycyrrhizae uralensis, licorice root), gypsum (calcium sulfate), and Bing-Pian (Borneol), and it is used for antipyretic, cold, gingivitis and other inflammatory diseases [1]. There is a general perception that the use of toxic metals in medicines is an unacceptable risk, but an opposing opinion holds that realgar-containing traditional medicines are not necessarily toxic at clinical doses $[2,7]$.

We have recently shown that chemical form of realgar $\left(\mathrm{As}_{4} \mathrm{~S}_{4}\right)$ is a major determinant for its disposition and toxicity. For example, realgar-containing An-Gong-Niu-Huang Wan (安宫牛黄丸) was much less toxic in cultured cells [8], in acute animal studies [9], and in subchronic toxicology studies $[10,11]$. The present study was undertaken to evaluate the true risk of a realgar-containing $N H J D$, a most popular patent Chinese medicine, in cultured cells and in intact animals, as compared to common arsenicals. The results 
fortified our prior conclusions that chemical forms of metals are very important in determining the disposition and toxicity of metal-containing traditional medicines.

\section{Materials and Methods}

2.1. Chemicals. Realgar ( $>90 \%$ of $\left.\mathrm{As}_{4} \mathrm{~S}_{4}\right)$, and realgar (6.4\%)-containing NHJD were obtained from Beijing TongRen-Tang Technologies Co., Ltd., Beijing, China; The common arsenicals $\mathrm{As}_{2} \mathrm{~S}_{2}, \mathrm{As}_{2} \mathrm{O}_{3}, \mathrm{NaAsO}_{2}$, and $\mathrm{Na}_{2} \mathrm{HAsO}_{4}$. $7 \mathrm{H}_{2} \mathrm{O}$ were purchased from Sigma Chemical Company (St. Louis, Mo, USA), all chemicals were of reagent grade.

2.2. Cell Cultures and Treatments. Human pharyngeal carcinoma FaDu cells were obtained from Shanghai Institute of Biochemistry and Cell Biology (Shanghai, China) and cultured in DMEM media supplemented with $10 \%$ fetal bovine serum (FBS) with penicillin and streptomycin. Cells were cultured at $37^{\circ} \mathrm{C}$ in a $5 \% \mathrm{CO}_{2}$-humidified atmosphere. All chemicals were dissolved in dimethyl sulfoxide (DMSO) in $10-30 \mathrm{mM}$ and serially diluted in culture media before addition to the cultures at 5-6 different concentrations as indicated. For cytotoxic assay, chemicals were added to 96wells when initiating the culture, and $48 \mathrm{~h}$ later, the cytotoxicity was measured by the MTS assay as described previously [8]. For As uptake and accumulation studies, cells were exposed to the same concentration $(100 \mu \mathrm{M})$ for $30-120 \mathrm{~min}$, and cellular As was determined after thoroughly washing.

2.3. Animals and Treatments. Adult male and female Kunming mice $(22 \pm 2 \mathrm{~g})$ were purchased from the Animal Center of the Third Military Medical University (Chongqing, China). Mice were kept in a regulated environment $(22 \pm$ $1^{\circ} \mathrm{C}, 50 \pm 2 \%$ humidity) with a $12 \mathrm{~h}: 12 \mathrm{~h}$ light:dark cycle. All animal procedures follow the WHO Guidance of Humane Care and Use of Laboratory Animals.

Mice were orally administered with NHJD $(600 \mathrm{mg} / \mathrm{kg})$, realgar $(600 \mathrm{mg} / \mathrm{kg})$, and the equal amount of As doses as sodium arsenite $(36 \mathrm{mg} / \mathrm{kg})$ and sodium arsenate $(88 \mathrm{mg} / \mathrm{kg})$. The NHJD $600 \mathrm{mg} / \mathrm{kg}$ is approximately 2 times of clinical dose $(2000 \mathrm{mg} /$ day $/ 60 \mathrm{~kg}$ person, taken mouse-human extrapolation factor of 10). Animals were monitored closely for clinical symptoms after gavage, and tissues were harvested for analysis $8 \mathrm{hrs}$ later. The doses of arsenicals selection were based on our recent publications $[9,12]$.

2.4. Blood Biochemistry. Serum was separated from whole blood by standing for $1 \mathrm{hr}$, and blood biochemistry was determined with an autoanalyzer (GLAMOUR1600). The serum activities of alanine aminotransferase (ALT) and concentrations of blood urea nitrogen (BUN) were quantified to evaluate the hepatotoxicity and nephrotoxicity of animals treated with NHJD and various arsenicals.

2.5. Arsenic Determination. Total arsenic contents in cells and tissues were analyzed by atomic fluorescence spectrometry (AFS) as described previously [12]. Briefly, tissues were completely digested in nitric acid at $170^{\circ} \mathrm{C}$ for $2.5 \mathrm{hrs}$ and brought to $25 \mathrm{~mL}$ with distilled water, and $5 \mathrm{~mL}$ of the sample was mixed with $1 \mathrm{~mL} \mathrm{5 \%}$ thiourea-ascorbic acid solution. Following $30 \mathrm{~min}$ incubation, aliquots were used for quantification of As contents with atomic fluorescence spectrometry (Kechuang Haiguan Instrument Co. Ltd, Beijing, China). These assays were performed at the Guizhou Chemical Analysis Center of Chinese Academia of Sciences [12].

2.6. RNA Isolation and Real-Time RT-PCR Analysis. RNA isolation and real-time RT-PCR analysis approximate 50$100 \mathrm{mg}$ tissue was homogenized in $1 \mathrm{~mL}$ TRIzol agent (Invitrogen, Carlsbad, Calif, USA), and total RNA was extracted according to manufacturer's instructions, followed by purification with RNeasy columns (Qiagen, Valencia, Calif, USA). The quality of RNA was determined by the $260 / 280$ ratios, and by gel electrophoresis to visualize the integrity of $18 \mathrm{~S}$ and $28 \mathrm{~S}$ bands. Total RNA was reverse transcribed with MMLV reverse transcriptase and oligo-dT primers. The PCR primers were designed with Primer Express software (Applied Biosystems, Foster City, Calif, USA) as MT-1 (BC027262), forward: AATGTGCCCAGGGCTGTGT; reverse: GCTGGGTTGGTCCGATACTATT. The Power SYBR Green Mater Mix (Applied Biosystems, Foster City, CA, USA) was used for real-time RT-PCR analysis. The cycle threshold $(\mathrm{Ct})$ values of the interested genes were first normalized with $\beta$-actin of the same sample and expressed as percentage of controls.

2.7. Statistical Analysis. For cytotoxicity analysis, means and standard error were calculated from 5 separate cultures, and the $\mathrm{LC}_{50}$ values were estimated via graphics. For animal studies, means and standard error of 6 mice were calculated. Data were analyzed using a one-way analysis of variance (ANOVA), followed by Duncan's multiple range test. The significant level was set at $P<0.05$ in all cases.

\section{Results}

3.1. Cytotoxicity of NHJD and Arsenicals in Human Pharyngeal FaDu Cells. Differential cytotoxicity between realgarcontaining An-Gong-Niu-Huang Wan and arsenicals was evident in human nasopharyngeal carcinoma FaDu cells [8]. Thus, the cytotoxicity potential of NHJD and arsenicals was examined in this cell line. Figure 1 illustrated that the $\mathrm{LC}_{50}$ at $48 \mathrm{~h}$ for realgar-containing $N H J D$ was $1200 \mu \mathrm{M}$, for realgar was $2000 \mu \mathrm{M}$. The most toxic arsenicals was sodium arsenite $(35 \mu \mathrm{M})$, sodium arsenate $(400 \mu \mathrm{M})$, arsenic disulfide $\left(\mathrm{As}_{2} \mathrm{~S}_{2}\right.$, $2000 \mu \mathrm{M})$, and arsenic trioxide $\left(\mathrm{As}_{2} \mathrm{O}_{3}, 280 \mu \mathrm{M}\right)$.

3.2. Accumulation of Arsenic in Human Pharyngeal FaDu Cells. Confluent FaDu cells were exposed to NHJD and arsenicals, all at the $100 \mu \mathrm{M}$ concentrations for $30 \mathrm{~min}$, and cultures were thoroughly washed and cellular uptake of As were determined as described in Methods. The results (Figure 2) show dramatic difference in cellular arsenic accumulation, NHJD, and realgar treatments resulted in 100-200 ng As/mg cellular protein, while sodium arsenite and sodium arsenate resulted in 1360 and $470 \mathrm{ng} \mathrm{As} / \mathrm{mg}$ 


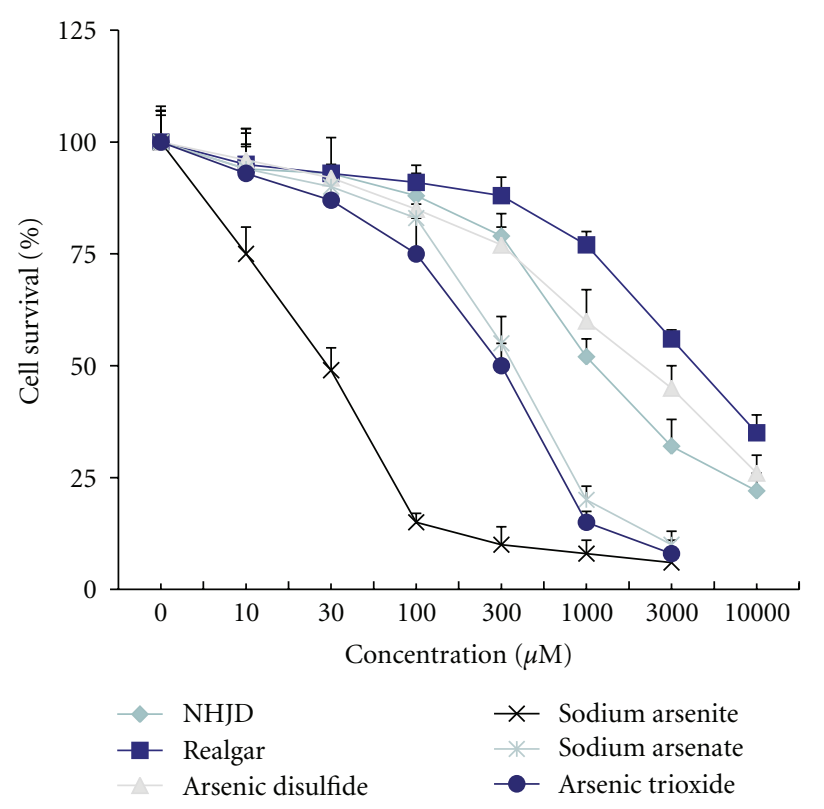

Figure 1: Human nasopharyngeal carcinoma FaDu cells were exposed to chemicals for $48 \mathrm{~h}$ and toxicity was determined by the MTS assay. The rank orders of $\mathrm{LC}_{50}$ are sodium arsenite $(35 \mu \mathrm{M})>$ arsenic trioxide $(280 \mu \mathrm{M})$, arsenate $(400 \mu \mathrm{M})>$ NHJD $(1200 \mu \mathrm{M})>$ realgar $\left(\mathrm{As}_{2} \mathrm{~S}_{2}, 2000 \mu \mathrm{M} ; \mathrm{As}_{4} \mathrm{~S}_{4}, 3000 \mu \mathrm{M}\right)$. Data are mean $\pm \mathrm{SE}$ of 5 separate experiments.

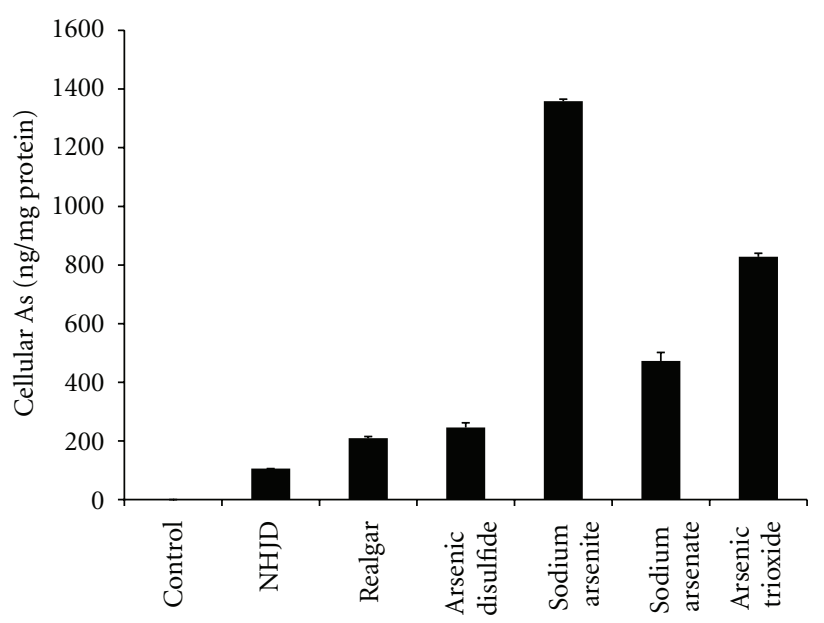

Figure 2: Cellular As accumulation. FaDu cells were exposed to $100 \mu \mathrm{M}$ of arsenicals for $30 \mathrm{~min}$. After washing 3 times in PBS, cells were harvested; cellular protein determined and As contents were determined by atomic fluorescence spectrometry (AFS). Data are mean \pm SE of 3 separate experiments.

protein, respectively. Similar results were also obtained after $60 \mathrm{~min}$ and $120 \mathrm{~min}$ exposure (data not shown).

\subsection{Blood Biochemistry of NHJDP and Arsenical Treatments} in Mice. Mice were orally administered with NHJD $(600 \mathrm{mg} /$ $\mathrm{kg})$, realgar $(600 \mathrm{mg} / \mathrm{kg}$, equivalent to reaglar in $N H J D)$, and the equal amount of As doses of sodium arsenite
TABLE 1: Serum ALT and BUN concentrations in mice treated with NHJD and arsenicals.

\begin{tabular}{lccc}
\hline Groups & Dose & ALT (U/L) & BUN (mmol/L) \\
\hline Control & 0 & $45.3 \pm 5.1$ & $11.3 \pm 0.1$ \\
NHJD & $600 \mathrm{mg} / \mathrm{kg}$ & $64.3 \pm 18.2$ & $13.6 \pm 2.2$ \\
Realgar & $600 \mathrm{mg} / \mathrm{kg}$ & $52.8 \pm 12.1$ & $11.2 \pm 2.3$ \\
Arsenic disulfide & $600 \mathrm{mg} / \mathrm{kg}$ & $58.2 \pm 9.0$ & $11.9 \pm 1.0$ \\
Sodium arsenite & $36 \mathrm{mg} / \mathrm{kg}$ & $103 \pm 31.4^{*}$ & $15.6 \pm 3.0^{*}$ \\
Sodium arsenate & $88 \mathrm{mg} / \mathrm{kg}$ & $92.5 \pm 18.3^{*}$ & $14.2 \pm 1.7^{*}$ \\
\hline
\end{tabular}

Data are mean \pm SE, $n=6 . * P<0.05$.

$(36 \mathrm{mg} / \mathrm{kg})$ and sodium arsenate $(88 \mathrm{mg} / \mathrm{kg})$. Animals were killed $8 \mathrm{hr}$ later and blood biochemistry was performed. The results (Table 1) show that the elevations of serum ALT and BUN after arsenite and arsenate, but these parameters were unaltered after $N H J D$, and realgar. Histopathology was consistent with blood biochemistry, showing more severe liver and kidney damage after arsenite and arsenate, but mild or absent after NHJD and realgar [13].

3.4. Accumulation of Arsenic in Liver and Kidneys after NHJD and Arsenical Treatments in Mice. Mice were orally administered with NHJD $(600 \mathrm{mg} / \mathrm{kg})$, realgar $(600 \mathrm{mg} / \mathrm{kg}$, equivalent to realgar in NHJD), and the equal amount of As doses of sodium arsenite $(36 \mathrm{mg} / \mathrm{kg})$ and sodium arsenate $(88 \mathrm{mg} / \mathrm{kg})$. Animals were killed $8 \mathrm{hr}$ later and tissue As accumulation was determined. The results (Figure 3 ) show that the dramatic difference in tissue arsenic accumulation, NHJD and reaglar treatments resulted in approximately $200 \mathrm{ng}$ As/g liver, while arsenite (6200 ng/g liver) and arsenate $(3320 \mathrm{ng} / \mathrm{g}$ liver) produced significant As accumulation. Renal As contents were under detection limits for NHJD and realgar, but reached $3350 \mathrm{ng} / \mathrm{g}$ kidney after arsenite and 1500 ng/g kidney after arsenate.

3.5. Expression of Metallothionein-1 in Liver and Kidneys. Figure 4 shows the expression of metallothionein-1 (MT1) in liver and kidney. MT is a small, cysteine-rich, metalbinding protein playing an important role in metal detoxication [14]. MT overexpression is a sensitive biomarker for arsenic-induced stress [15]. As shown in Figure 4, hepatic MT-1 was increased 5-7-folds after arsenite and arsenate, but was not altered after NHJD and realgar. As shown in Figure 4, bottom, renal MT-1 transcript levels were also increased after arsenite (5-fold) and arsenate (2-fold), respectively. In comparison, $N H J D$ and realgar did not produce significant elevation in renal MT-1 transcripts.

\section{Discussion}

The present study clearly demonstrated that realgar and realgar-containing NHJD were much less toxic than sodium arsenite and arsenate in cultured cells and in mice, as evidenced by $\mathrm{LC}_{50}$ values, the elevated serum ALT and BUN concentrations in mice. Toxicokinetically, much less As was accumulated in the cells or in tissues after realgar and 


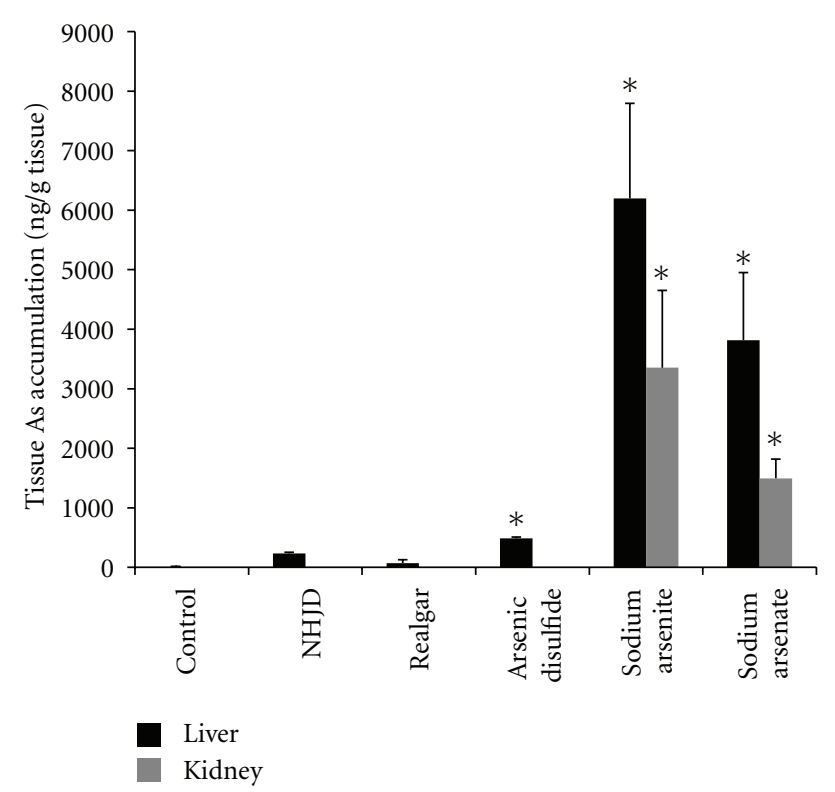

Figure 3: As accumulation in liver and kidney. Mice were orally given NHJD $(600 \mathrm{mg} / \mathrm{kg})$, realgar $(600 \mathrm{mg} / \mathrm{kg})$, arsenic disulfide $(600 \mathrm{mg} / \mathrm{kg})$, sodium arsenite $(36 \mathrm{mg} / \mathrm{kg})$, or sodium arsenate $(88 \mathrm{mg} / \mathrm{kg})$. Tissues were collected $8 \mathrm{~h}$ later for analysis by atomic fluorescence spectrometry (AFS). Data are mean \pm SE of 6 mice and expressed as ng As/g wet tissue. * Significantly different from controls $* P<0.05$.

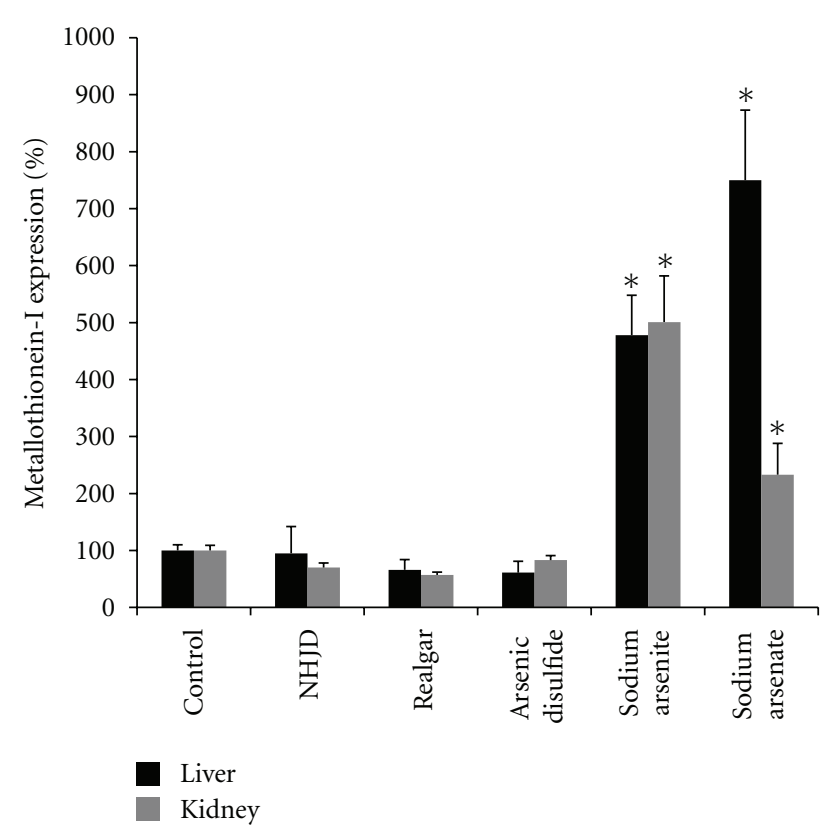

FIGURE 4: Relative transcript levels of metallothionein-1 (MT-1) in liver and kidney. Mice were orally given NHJD $(600 \mathrm{mg} / \mathrm{kg})$, realgar $(600 \mathrm{mg} / \mathrm{kg})$, arsenic disulfide $(600 \mathrm{mg} / \mathrm{kg})$, sodium arsenite $(36 \mathrm{mg} / \mathrm{kg}$ ), sodium arsenate $(88 \mathrm{mg} / \mathrm{kg}$ ), or distilled water (Control). Tissues were collected $8 \mathrm{~h}$ later for total RNA isolation, followed by real-time RT-PCR analysis. Data are mean \pm SE of 6 mice. * Significantly different from controls $P<0.05$.
NHJD. Furthermore, the expression of stress-related genes, namely, MT-1, was increased 2-7-folds after sodium arsenite and arsenate in the liver and kidneys, but was basically unaltered after realgar and $N H J D$, consistent with tissue damage. The present study fortified our recent observations in cultured cells [8] and in intact animals [9-13], indicating that realgar and realgar-containing NHJD are different from sodium arsenite and arsenate and clearly demonstrate that the chemical forms of arsenicals underlies their disposition and toxicity potentials.

Arsenic has been used as a remedy and a poison since ancient times. In addition to the use of arsenic compounds in cancer chemotherapy $[16,17]$, realgar has been included in 22 oral patent traditional remedies according to Pharmacopeia of China [1], and was claimed to have many beneficial effects for various diseases $[1-3,16,17]$. However, the major concern is their toxicity potential, which limits many realgar-containing remedies. NHJD is a most popular realgar-containing traditional Chinese medicine (http://www.wickpedia.org/) available in Chinese grocery stores in the USA and in the Europe and is used for many inflammatory diseases [1]. To critically evaluate its toxicity potential is important for safely use of realgar and realgarcontaining traditional medicines in the treatment of various inflammatory diseases.

Arsenic exists in the trivalent $\left(\mathrm{As}^{3+}\right.$, arsenite) and pentavalent $\left(\mathrm{As}^{5+}\right.$, arsenate) forms and is widely distributed in nature. In general, sodium arsenate $\left(\mathrm{LD}_{50} 112-175 \mathrm{mg} / \mathrm{kg}\right)$ is $4-5$ times less acutely toxic than sodium arsenite $\left(\mathrm{LD}_{50}\right.$ $15-44 \mathrm{mg} / \mathrm{kg}$ ), and the pentavalent organic arsenicals MMA, DMA, and TMA are 40-100 times less acutely toxic than arsenite [18]. Arsenicals in seafood mainly exist as organic forms, such as arsenobetaine, arsenosugar, and arsenocholine, with acute oral $\mathrm{LD}_{50}$ values $100-500$-fold above arsenite or arsenate [2]. In traditional medicines, the oral $\mathrm{LD}_{50}$ for arsenic trioxide (i.e., arsenolite) in mice is $32-$ $39 \mathrm{mg} / \mathrm{kg}$, but the $\mathrm{LD}_{50}$ for realgar is $3.2 \mathrm{~g} / \mathrm{kg}$ [2], a 100 -fold difference in acute toxicity. Thus, arsenical toxicity is highly dependent on the chemical form, and realgar $\left(\mathrm{As}_{4} \mathrm{~S}_{4}\right)$ is much less acutely toxic than arsenic trioxide $\left(\mathrm{As}_{2} \mathrm{O}_{3}\right)$ and is also much less acutely toxic than sodium arsenite $\left(\mathrm{NaAsO}_{2}\right)$ and arsenate $\left(\mathrm{Na}_{2} \mathrm{HAsO}_{4}\right)$ in the present study.

It is generally assumed that the severity of poisoning is related to the total amount of poison ingested, and assessment of health risk associated with arsenic exposure from human ingestion of traditional medicines has typically taken this tactic [4-7]. However, the present study clearly showed that realgar was poorly accumulated into the cells and tissues and was unable to reach a critical concentration to cause tissue damage as compared to the same amount of arsenic given as arsenite and arsenate, with tremendous differences in their tissue contents. The disposition of these arsenicals in the body depends on various key factors including solubility, absorption, distribution, and excretion [2]. For example, the average total arsenic in NHJD is about $7 \pm 1 \%$ (i.e., $70,000 \mathrm{ppm}$ ), corresponding to $28 \mathrm{mg}$ arsenic per pill, of which only $1 \mathrm{mg}$ arsenic finds its way into the blood stream, that is, only $4 \%$ of intake realgar is bioavailable [19]. Compared to realgar, $80 \%$ of orally given 
sodium arsenite and arsenate can be absorbed from the gastrointestinal tract, with much higher plasma As levels and tissue distribution $[2,18]$. The bioavailability is a critical determinant of efficacy and toxicity of arsenical compounds. Thus, it is the amount of toxicants to the target organ, rather than the amount ingested or inhaled that makes a poison [20].

Various stresses have been proposed as an important mechanism involved in arsenic toxicity and carcinogenesis. MT is a small, cysteine-rich, metal-binding protein playing an important role in metal toxicity [14]. Induction of MT by arsenicals is dependent on arsenic forms, with sodium arsenite is the most potent and efficient inducer followed by arsenate and organic arsenicals, such as MMA and DMA [21], and MT-null mice were susceptible to chronic arsenic-induced hepatotoxicity and nephrotoxicity [22]. MT induction is considered an adaptive mechanism to toxic metal-induced oxidative stress $[14,15]$ and can be used as an indicator for arsenic-induced stress. In the present study, hepatic and renal MT was induced by sodium arsenite and arsenate, but was basically unaltered by realgar and NHJD, fortifying the observations from blood biochemistry that realgar and NHJD are much less acutely toxic than sodium arsenite and arsenate.

Traditional medicines are based on empirical experience and have their own theory and are generally safe at clinical doses. The regulation of metal-containing traditional medicines has been a topic of debate $[2-7,13,23-25]$. We have been invited to write two reviews on this topic for arsenic (J Pharmcol Exp Ther [2]) and for Hg (Exp Biol Med [26] and have challenged this bias by studying the relative safety of Liu-Shen-Wan (六神丸, As) [12], An-GongNiu-Huang-Wan (安宫牛黄丸, As+Hg) [9-11], and Zhu-ShaAn-Shen-Wan (朱砂安神丸, Hg) [27]. In the present study, $N H J D$ is unique in that it is the most popular traditional medicine available not only in China [1], but also in Chinese grocery stories worldwide. To study its relative safety is of clinical significance.

Realgar is less toxic than arsenic oxide yet effective in cancer chemotherapy based on the recent literature [23]. However, this does not imply that realgar and NHJD are nontoxic. High dose of realgar for the long-term use did produce toxicity to the liver and kidneys [24], similarly, longterm use NHJD was reported to produce hepatotoxicity and nephrotoxicity [25]. In the evaluation of realgar and realgarcontaining NHJD in the treatment of various diseases, the balance of the benefit and risk is important. "Dose makes a poison." Although realgar and NHJD are less toxic than sodium arsenite and arsenate, high-dose and longterm administration should be avoided to reduce undesired adverse effects and toxicity $[2,18]$.

In summary, the present study clearly demonstrated that realgar and realgar-containing NHJD are much less toxic to the cultured cells and to the intact animals, as compared to sodium arsenite and arsenate. The chemical forms of arsenicals determine their tissue accumulation and toxicity potentials, and thus the use of the total content of As to evaluate realgar-containing traditional medicines is inappropriate.

\section{Abbreviations}

\begin{tabular}{|c|c|}
\hline NHJD: & $\begin{array}{l}\text { Niu-Huang-Jie-Du Pian (牛黄解毒片), a } \\
\text { realgar-containing traditional medicine }\end{array}$ \\
\hline MTS: & $\begin{array}{l}\text { [(3-(4,5-dimethylthiazol-2-yl)-5-(3- } \\
\text { carboxymethoxyphenyl)-2-(4- } \\
\text { sulfophenyl })-2 H \text {-tetrazolium })\end{array}$ \\
\hline MT-1: & Metallothionein-1 \\
\hline As: & Arsenic \\
\hline $\mathrm{Hg}:$ & Mercury. \\
\hline
\end{tabular}

\section{Acknowledgment}

This paper was supported by Guizhou Traditional Medicine Administration (QZYY2010) and Guizhou Science and Technology Foundation (TZJF2009-41 and 2010-5).

\section{References}

[1] Pharmacopoeia of China, Chemical Industry Press, Beijing, China, 2010.

[2] J. Liu, Y. F. Lu, Q. Wu, R. A. Goyer, and M. P. Waalkes, "Mineral arsenicals in traditional medicines: orpiment, realgar, and arsenolite," Journal of Pharmacology and Experimental Therapeutics, vol. 326, no. 2, pp. 363-368, 2008.

[3] A. Kumar, A. G. C. Nair, A. V. R. Reddy, and A. N. Garg, "Bhasmas: unique ayurvedic metallic-herbal preparations, chemical characterization," Biological Trace Element Research, vol. 109, no. 3, pp. 231-254, 2006.

[4] E. Ernst, "Toxic heavy metals and undeclared drugs in Asian herbal medicines," Trends in Pharmacological Sciences, vol. 23, no. 3, pp. 136-139, 2002.

[5] K. Cooper, B. Noller, D. Connell et al., "Public health risks from heavy metals and metalloids present in traditional Chinese medicines," Journal of Toxicology and Environmental Health, Part A, vol. 70, no. 19, pp. 1694-1699, 2007.

[6] R. B. Saper, S. N. Kales, J. Paquin et al., "Heavy metal content of ayurvedic herbal medicine products," JAMA-Journal of the American Medical Association, vol. 292, no. 23, pp. 2868-2873, 2004.

[7] J. J. Mao and K. Desai, "Metal content in ayurvedic medicines," JAMA-Journal of the American Medical Association, vol. 301, no. 3, p. 271, 2009.

[8] Q. Wu, Y. F. Lu, J. Z. Shi, J. Liu, and J. S. Shi, "Chemical form of metals in traditional medicines underlines potential toxicity in cell cultures," Journal of Ethnopharmacology, vol. 134, no. 3, pp. 839-843, 2011.

[9] Y. F. Lu, J. W. Yan, Q. Wu, J. Z. Shi, J. Liu, and J. S. Shi, "Realgarand cinnabar-containing An-Gong-Niu-Huang Wan (AGNH) is much less acutely toxic than sodium arsenite and mercuric chloride," Chemico-Biological Interactions, vol. 189, no. 1-2, pp. 134-140, 2010.

[10] Y. F. Lu, Q. Wu, J. W. Yan, J. Z. Shi, J. Liu, and J. S. Shi, "Realgar, cinnabar and An-Gong-Niu-Huang Wan (AGNH) are much less chronically nephrotoxic than common arsenicals and mercurial," Experimental Biology and Medicine, vol. 236, no. 2, pp. 233-239, 2011.

[11] Y. F. Lu, Q. Wu, S. X. Liang, J. W. Miao, J. S. Shi, and J. Liu, "Evaluation of hepatotoxicity potential of cinnabarcontaining An-Gong-Niu-Huang Wan, a patent traditional Chinese medicine," Regulatory Toxicology and Pharmacology, vol. 60 , no. 2 , pp. 206-211, 2011. 
[12] J. Liu, S. X. Liang, Y. F. Lu, J. W. Miao, Q. Wu, and J. S. Shi, "Realgar and realgar-containing Liu-Shen-Wan are less acutely toxic than arsenite and arsenate," Journal of Ethnopharmacology, no. 1, pp. 26-31, 2010.

[13] J. W. Miao, X. L. Liu, S. X. Liang et al., "Comparative study on acute toxicity of Niu-Huang-Jie-Du Tablets and other inorganic arsenic compounds," Chinese Journal of Pharmacology and Toxicology, vol. 25, pp. 70-74, 2011.

[14] C. D. Klaassen, J. Liu, and S. Choudhuri, "Metallothionein: an intracellular protein to protect against cadmium toxicity," Annual Review of Pharmacology and Toxicology, vol. 39, pp. 267-294, 1999.

[15] J. Liu, M. B. Kadiiska, Y. Liu, T. Lu, W. Qu, and M. P. Waalkes, "Stress-related gene expression in mice treated with inorganic arsenicals," Toxicological Sciences, vol. 61, no. 2, pp. 314-320, 2001.

[16] P. J. Dilda and P. J. Hogg, "Arsenical-based cancer drugs," Cancer Treatment Reviews, vol. 33, no. 6, pp. 542-564, 2007.

[17] J. Wu, Y. Shao, J. Liu, G. Chen, and P. C. Ho, "The medicinal use of realgar $(\operatorname{As}(4) S(4))$ and its recent development as an anticancer agent," Journal of Ethnopharmacology, vol. 35, pp. 595-602, 2011.

[18] ATSDR, Toxicological Profile for Arsenic, Agency for Toxic Substances and Disease Registry, Atlanta, Ga, USA, 2005.

[19] I. Koch, S. Sylvester, V. W. M. Lai, A. Owen, K. J. Reimer, and W. R. Cullen, "Bioaccessibility and excretion of arsenic in Niu Huang Jie Du Pian pills," Toxicology and Applied Pharmacology, vol. 222, no. 3, pp. 357-364, 2007.

[20] L. Lehman-McKeeman, "Paracelsus and formaldehyde 2010: the dose to the target organ makes the poison," Toxicological Sciences, vol. 116, no. 2, pp. 361-363, 2010.

[21] H. Kreppel, J. W. Bauman, J. Liu, J. M. McKim Jr., and C. D. Klaassen, "Induction of metallothionein by arsenicals in mice," Fundamental and Applied Toxicology, vol. 20, no. 2, pp. 184-189, 1993.

[22] J. Liu, Y.-P. Liu, R. A. Goyer, W. Achanzar, and M. P. Waalkes, "Metallothionein-I/II null mice are more sensitive than wildtype mice to the hepatotoxic and nephrotoxic effects of chronic oral or injected inorganic arsenicals," Toxicological Sciences, vol. 55, no. 2, pp. 460-467, 2000.

[23] L. Wang, G. B. Zhou, P. Liu et al., "Dissection of mechanisms of Chinese medicinal formula Realgar-Indigo naturalis as an effective treatment for promyelocytic leukemia," Proceedings of the National Academy of Sciences of the United States of America, vol. 105, no. 12, pp. 4826-4831, 2008.

[24] L. Wei, P. Liao, H. Wu et al., "Metabolic profiling studies on the toxicological effects of realgar in rats by (1)H NMR spectroscopy," Toxicology and Applied Pharmacology, vol. 234, no. 3, pp. 314-325, 2009.

[25] L. Zhang, S. H. Gao, C. F. Zhou, R. C. Lin, and C. H. Liu, "From Niu-Huang-Jie-Du Pian to safety evaluation of arseniccontaining traditional medicines," ZhongGuoZhongYaoZaZhi, vol. 31, pp. 2010-2013, 2006.

[26] J. Liu, J. Z. Shi, L. M. Yu, R. A. Goyer, and M. P. Waalkes, "Mercury in traditional medicines: is cinnabar toxicologically similar to common mercurials?" Experimental Biology and Medicine, vol. 233, no. 7, pp. 810-817, 2008.

[27] J. Z. Shi, F. Kang, Q. Wu, Y. F. Lu, J. Liu, and Y. J. Kang, "Cinnabar-containing Zhu-Sha-An-Sheng Wan is much less chronically nephrotoxic than mercury chloride and methylmercury in rats," Toxicology Letters, vol. 200, pp. 194200, 2011. 

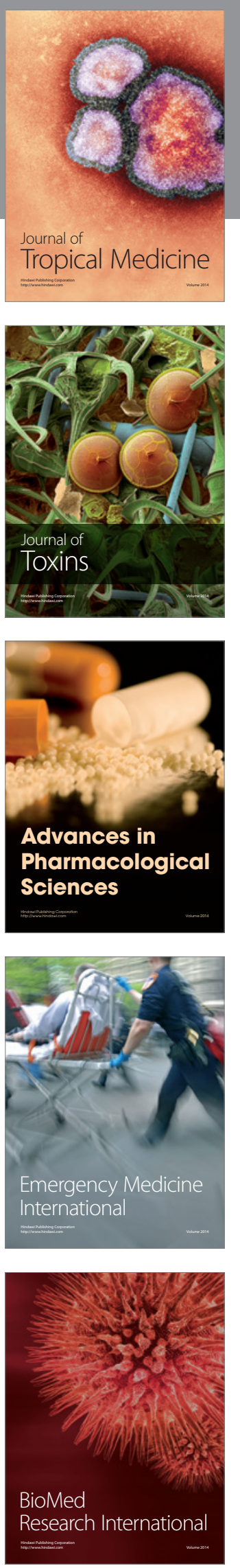
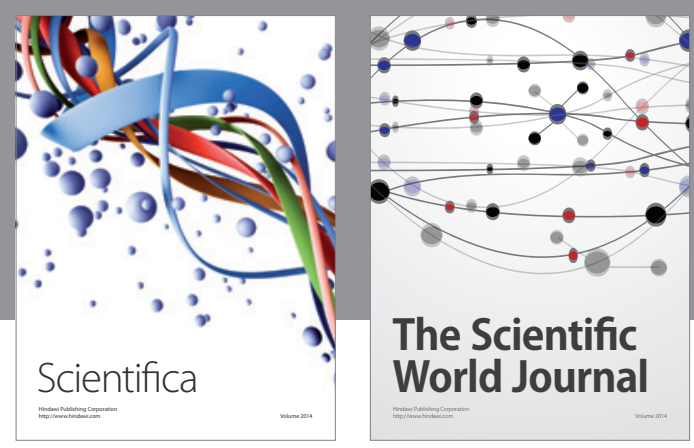

The Scientific World Journal
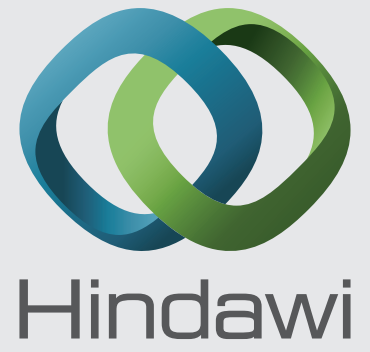

Submit your manuscripts at

http://www.hindawi.com
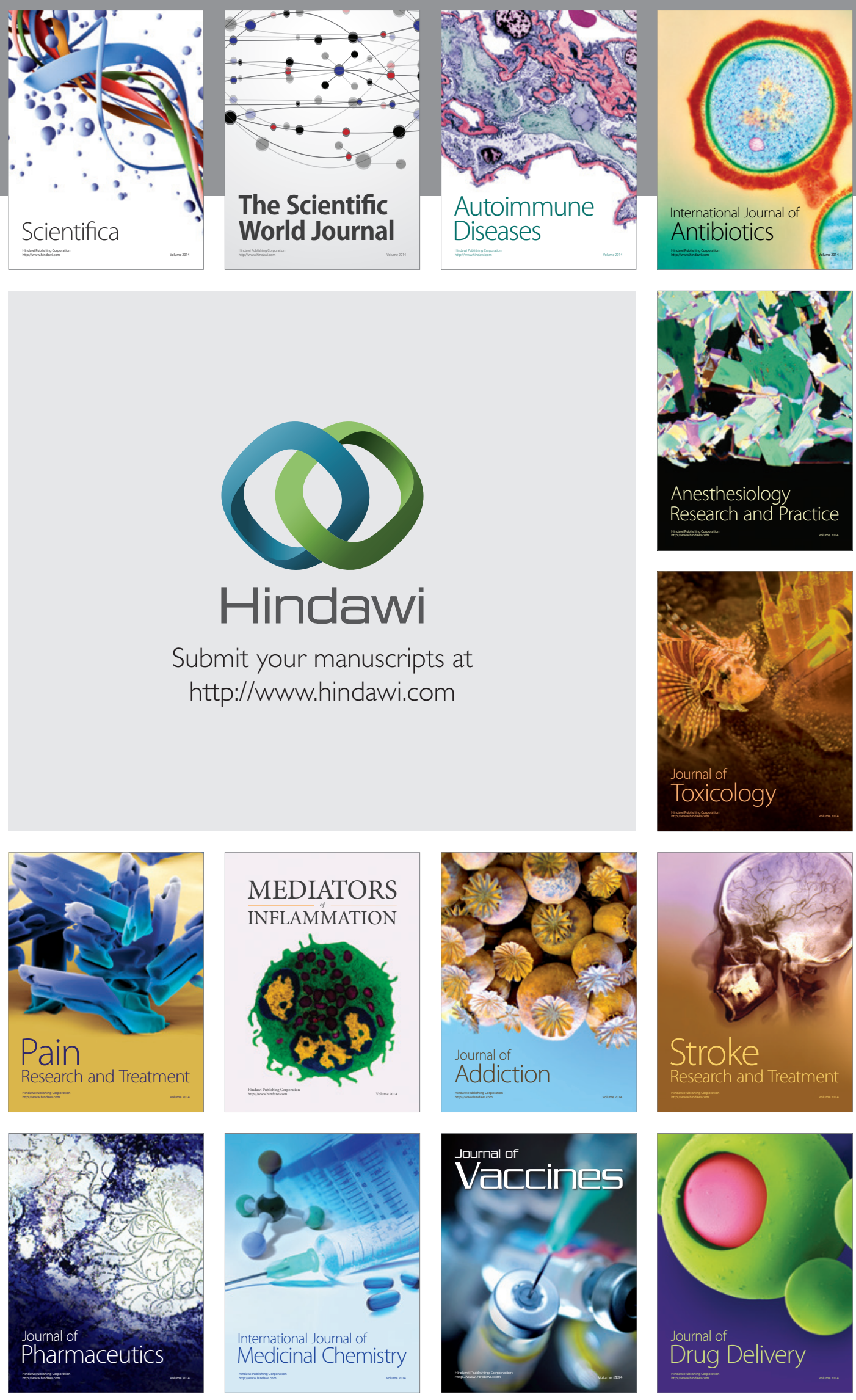